\title{
L'Interdiction, or, Balzac on the Margins of Law and Realism
}

The striking title of Honoré de Balzac's 1836 novella L'Interdiction refers to a single, particularly powerful, form of legal speech act: the one known in nineteenth-century France as interdiction, meaning not some general act of prohibition, but the specific ruling whereby an adult was judged legally incompetent of managing his own affairs. ${ }^{1}$ In a sense, this is an act of speaking that deprives another of speech: in French, someone who is said to be interdit is speechless or dumbstruck. ${ }^{2}$ The legal interdit is, in any case, socially and economically powerless, the administration of his affairs being handed over to a tutor. Balzac's L'Interdiction is purely and simply the story of an attempted interdiction and, more specifically, of an investigating magistrate or juge d'instruction's preliminary inquiry into a demande en interdiction, as the relevant suit was known. The parties to the suit are the marquis and the marquise d'Espard, the proudest of the old aristocracy. The pair have been estranged for more than a decade when the novel begins; he is raising their two children without her. She now claims that he is mad, and wishes to have him declared incompetent, or interdit.

This, then, is one of the 'poems and dramas' that the sometime law student Honoré de Balzac - in the words of his friend Théophile Gautier - knew how to extract from the unpromising texts of black-letter law. ${ }^{3}$ One of the work's primary concerns, indeed, is 'justice', and its most obvious purpose is to rehearse the familiar western literary tension between justice

\footnotetext{
All translations are my own unless otherwise indicated.

${ }^{1}$ Throughout this article, I simply use the word 'interdiction' to refer to the suit and the resulting order; I also use the participial adjective interdit to describe a person who is the subject of such an order.

${ }^{2}$ The 1835 Dictionnaire de l'Académie française, for instance, gives among the meanings of the adjective interdit 'stunned, troubled, who is unable to reply'.

${ }^{3}$ Théophile Gautier, Honoré de Balzac (Poulet-Malassis, 1859), p. 69. There is a wealth of critical material on Balzac's legal training and his engagement with the law in La Comédie humaine, but the following may be consulted with particular profit: Adrien Peytel, Balzac, juriste romantique (Ponsot, 1950); Marie-Henriette Faillie, La Femme et le Code civil dans 'La Comédie humaine' de Balzac (Didier, 1968); Tim J. Farrant, 'Le Rôle des modèles judiciaires dans l'élaboration du discours balzacien', 44 Cahiers de l'association internationale des études françaises, 177; Pierre-François Mourier, Balzac: l'injustice de la loi (Michalon, 1996); and Michel Lichtlé, Balzac, le texte et la loi (Presses de l’Université Paris-Sorbonne, 2012).
} 
understood as an aspirational ideal, on the one hand, and as a flawed set of social institutions, on the other. The novella opens programmatically in this respect: Eugène de Rastignac, the hero of Balzac's successful novel of the previous year Le Père Goriot, takes his old friend the doctor Bianchon aside and asks him a favour. Rastignac, who hopes to make Mme d'Espard his mistress, has discovered that Bianchon's uncle, Jean-Jules Popinot, is the magistrate assigned to hear Mme d'Espard's petition to have her husband declared incompetent. Rastignac persuades Bianchon to visit his uncle and put in a good word on Mme d'Espard's behalf. ${ }^{4}$ The opening finds us, that is, in that marginal zone where the supposedly impartial letter of the law intersects with what in Le Père Goriot is called 'cette haute jurisprudence sociale qui, bien apprise et bien pratiquée, mène à tout' [that high social jurisprudence which, studied and practised well, can take one anywhere; 109]; the zone, that is, where influence, string-pulling and the trade in favours hold sway. The irremediable vulnerability of law-as-justice to this other kind of social law is a central theme of the novella. Somewhat obscured by this, however, and more important to my analysis in this article, is the novella's engagement with an important literary quarrel of the 1830 s and '40s - the quarrel between the aesthetic sensibility that was already being called 'idealism', on the one hand, and that of the literature that would eventually come to be known as 'realism', on the other. The legal dispute at the heart of L'Interdiction in fact operates as a metaphor for the tension between these two narrative modes, and while the novella's plot superficially flirts with both, its structure, as we shall see, heralds the inevitable triumph of the latter.

\section{On Interdiction}

\footnotetext{
${ }^{4}$ See Honoré de Balzac, L'Interdiction, in volume III of La Comedie humaine, ed. by Pierre-Georges Castex, 12 vols (Gallimard 'Pléiade', 1976), pp. 403-93. All references to this edition are given in the text and refer to volume III unless a volume number is given.
} 
What specifically attracted Balzac to the theme of interdiction? As the great novelist of family life, in both its joys and its tensions, Balzac no doubt saw in interdiction a particularly vivid means of dramatizing the latter. If in his 1842 'Avant-propos’ to La Comédie humaine Balzac speaks conservatively of an abstract 'Famille' as 'le véritable élément social' [the true social unit; 1, 13], the fact remains that his work was consistently interested in the tribulations and even breakdowns of that elementary unit, in the fallibility and messiness elided by that ideologically loaded capital 'F. ${ }^{5}$ And interdiction was messy: it was, after all, one of a small class of adversarial legal proceedings in which the parties were almost by definition close kin. Article 490 of the Civil Code assigns standing to bring interdiction proceedings to any relative of the allegedly afflicted person, then adds, significantly, that 'the same goes for either spouse' ${ }^{6}$ Interdiction was not just a family affair, then: along with a request for a legal separation, it was more specifically one of only two suits a wife could file against her husband, and thus, indeed, one of only two suits a wife could file independently, without her husband's written permission. ${ }^{7}$ It is difficult to exaggerate the ideological perturbation at work in such a provision, in a document whose conceptual lynchpin, as legal historians have long noted, was the authority and integrity of the père de famille, that modern reworking of the Roman paterfamilias. Conceived as a means of restoring social stability after the alleged excesses of the Revolution, the Civil Code's family regime was unapologetically patriarchal, imposing a duty of wifely obedience (art. 213) and filial respect 'at all ages' (art. 371); conferring extensive paternal power including a right of punitive detention (arts 371-80); and, perhaps most notoriously, making the husband virtual tutor to his wife, who was deprived of the management of her property for the duration of the marriage (art. 217).

\footnotetext{
${ }^{5}$ On the complexity of Balzac's vision of the family, see perhaps most influentially Michael Lucey, The Misfit of the Family: Balzac and the Social Forms of Sexuality (Duke University Press, 2003).

${ }^{6}$ Code civil des Français: édition originale et seule officielle (Paris: Imprimerie de la République, 1804), art. 490. Subsequent references to the Civil Code are given in the text, by article number.

${ }^{7}$ Article 217 of the Civil Code deprived the married woman of all independent legal as well as financial initiative, requiring that she act in concert with her husband or obtain his written permission.
} 
When one considers this ideological background, the articles on interdiction seem all the more striking - not least in their willingness to countenance a radical gender role-reversal whereby 'the wife may be named tutor to her husband' (art. 507). Indeed, the symbolic importance of the père de famille within the fabric of the Code, and the vast legal and financial powers practically accorded to him in its various provisions, paradoxically meant that interdiction was imagined primarily as a suit that might target husbands and fathers (since theirs was the only sort of incompetence that was presumed to be financially consequential). While debating the relevant articles, the drafters of the Civil Code had been wracked with anxiety about the propriety of allowing such an attack - especially when instigated by the wife - against the foundational figure of their socio-legal design. ${ }^{8}$ Yet running between the lines of the drafters' agonized discussions was a set of tacit assumptions that the Civil Code's greatest modern commentator, Xavier Martin, expresses with particular eloquence:

The importance of property in the framework of the French Civil Code is well known, yet it is not always understood that property, in the hands of its owners, was intended to have the precise and socially crucial power of ensuring that the heir apparent remained respectful. Thus the father was regarded only as being, a priori, a property-owner [...].The bon père de famille is a man who manages his patrimony rationally, thus no doubt ensuring or preparing the way for his family’s happiness, but primarily maintaining domestic order for the good of society. ${ }^{9}$

In this conception, the father whose economic behaviour becomes seriously irrational is not, strictly speaking, a father at all; his legal disenfranchisement, even pursued to the topsy-turvy point of his wife's assuming control of his affairs, would thus only give formal effect to a preexisting state of fact. Indeed, interdiction would in this sense precisely preserve the ideological

\footnotetext{
${ }^{8}$ Recueil complet des travaux préparatoires du Code civil, ed. by Pierre-Antoine Fenet, 15 vols (Videcoq, 1836), 10, 689.

${ }^{9}$ Xavier Martin, 'The Paternal Role and the Napoleonic Code’, trans. Trista Selous, in Paternity and Fatherhood: Mythis and Realities, ed. by Lieve Spaas (Macmillan, 1998), pp. 27-39 (p. 31), internal citations omitted.
} 
figure of the père de famille from contamination by the mental feebleness of certain, all-too real fathers.

The family strife and ideological confusion that almost certainly lay behind any individual interdiction suit was a rich source of drama, then. Yet the title L'Interdiction first appears in a manuscript note made by Balzac prior to 1831, as one among a list of 'legal battles' that might make good stories, ${ }^{10}$ and this coupled with the final structure of the tale gives us every reason to suppose that the novelist was as intrigued by the legal process of interdiction, by its specific language and forensic character, as by the family dramas it revealed. The process of interdiction provided for by articles 489-512 of the Civil Code and clarified by articles 890-7 of the Code of Civil Procedure of 1806 was intended in some significant sense as a liberalization of earlier practices. Perhaps most importantly, the standard for 'rational' economic behaviour alluded to by Xavier Martin was set deferentially low: after much tense debate within the committee, the decision was made to remove mere profligacy (in French prodigalite) from among the reasons that might justify an interdiction suit. ${ }^{11}$ The scrupulous inquisitorial process required by the Code (dramatized by Balzac, if somewhat simplified for reasons of narrative expediency) was similarly intended to address perceived abuses of the practice under the Ancien Régime, where interdiction had ended up inhabiting what we might call the same conceptual neighbourhood as the infamous lettres de cachet, those instruments of summary detention and dispossession that were among the most deplored emblems of oldregime arbitrariness. If a Napoleonic citizen were to be deprived of his legal personhood, it would henceforth be on the determination of an impartial tribunal, and the mere fact of imprudent expenditure would, in theory at least, no longer be sufficient to justify such a radical remedy.

\footnotetext{
${ }^{10}$ See textual note to 'L'Interdiction,' in the Pléiade edition (p. 1380).

${ }^{11}$ See Recueil complet, 10, 689.
} 
Yet despite this evidence of an 'enlightened' approach to their subject matter, the drafters of the Code may be said to have operated in other respects in a rather old-fashioned way. Once profligacy was set aside, the causes for interdiction they retained were three: imbécillité, meaning something like a learning disability; démence, madness or senility; and fureur, a form of violent madness. But as the alienist Alexandre Brierre de Boismont lamented in 1830, these categories were judicial, not medical artefacts, inherited from Ancien Régime jurisprudence rather than informed by the current state of medical knowledge. ${ }^{12}$ Brierre de Boismont's treatise reflects and deplores the fact that, for the first four decades of the nineteenth century and despite the rise to prominence of psychiatry during that same period, interdiction remained entirely within the domain of legal disciplinary knowledge. The Code of Civil Procedure makes no mention of medical testimony, nor were litigants obliged to adduce medical evidence in support of their claim. Instead, everything in the codes appears to assume that judges were competent to assess the mental faculties of others, as if the difference between madness and sanity were only ever a matter of common sense.

In fact, Brierre de Boismont’s treatise was only one intervention in what Jan Goldstein identifies as a veritable campaign, beginning around 1820, whereby the newly professionalized psychiatric discipline attempted to assert control over those areas it regarded as its rightful epistemic province. This campaign, which culminated in a law of 1838 establishing a system of state mental asylums, publicized the pertinence of psychiatric knowledge to questions of legal competency even as it lamented the Code’s omission of that knowledge from the relevant judicial procedures. ${ }^{13}$ It is symptomatic, then, that while the interdiction suit dramatized by Balzac speaks the time-honoured language of the Code - the marquis d'Espard's behaviour, his wife’s lawyer insists, 'constitu[e] l'état de démence et d’imbécillité prévu par [le] Code

\footnotetext{
${ }^{12}$ See Alexandre Brierre de Boismont, Considérations médico-légales sur l'interdiction des aliénés (Baillière, 1830), pp. 1-3; also Code civil, art. 491.

${ }^{13}$ See Jan Goldstein, Console and Classify: The French Psychiatric Profession in the Nineteenth Century (University of Chicago Press, 2001; first pub. 1987), pp. 285-7.
} 
civil' [constitutes the state of madness and imbecility required by the Civil Code; 442] - the nature of that alleged madness is explicitly rendered in terms borrowed from the hobby-horse of 1830s psychiatric medicine: monomania (la monomanie, cf. 445, 447), specifically in the form of a pathological obsession with China, Chinese history, and Chinese customs. ${ }^{14}$ As Miranda Gill notes, psychiatrists of the July Monarchy (1830-48) became preoccupied by the 'fashionable new doctrine' of monomania, and through it began to regard various forms of eccentric or unusual behaviour as being, at bottom, mental pathologies. 'The pathologization of eccentricity', Gill argues, 'represents one of the most extreme attempts to medicalize deviance, for it restricted notions of normality and sanity to an increasingly narrow set of norms. ${ }^{15}$ Sure enough, the primary concern of Brierre de Boismont's 1830 pamphlet is that the current state of the law appears not to reach monomaniacs whose more insidious affliction, though apparently limited to discrete idées fixes or delusions, ought (Brierre asserts) to exclude them from full legal personhood. ${ }^{16}$

The particular fascination of interdiction proceedings, then, perhaps lay for Balzac in their status as the point of convergence for two normative discourses, both of which claim the right to determine which behaviours are socially admissible, and which unacceptably marginal: on the one hand, psychiatric discourse and especially the doctrine of monomania, which certainly fascinated the author Honoré de Balzac; ${ }^{17}$ and on the other, a legal discourse uniquely empowered to judge an individual's conduct with reference not to some prior, legislatively

\footnotetext{
${ }^{14}$ The choice of China is no doubt arbitrary. More precisely, China has in Balzac's work the very precise function of connoting the impossibly remote and therefore unimaginable, perhaps most famously in the 'Mandarin problem' posed by Rastignac to Bianchon in Le Père Goriot: had he the power to do so by thought alone, would he be willing to earn a fortune by striking dead a 'Mandarin' in China? (The virtuous Bianchon thinks not; Rastignac equivocates.) On the distant Mandarin and his eighteenth-century antecedents (Balzac falsely attributes the problem to Rousseau), see Michel Delon, 'De Diderot à Balzac, le paradoxe du mandarin', 3 Revue italienne d'études francaises, 1.

${ }^{15}$ Miranda Gill, Eccentricity and the Cultural Imagination in Nineteenth-Century Paris (Oxford University Press, 2009), pp. 239-40.

${ }^{16}$ See Brierre de Boismont, Considérations médico-légales sur l'interdiction, pp. 3-9.

${ }^{17}$ On Balzac's interest in contemporary psychiatry and especially monomania, see Lawrence Rothfield, Vital Signs: Medical Realism in Nineteenth-Century Fiction (Princeton University Press, 1992), ch. 3 (esp. pp. 62-3 on L'Interdiction).
} 
determined standard, but to a set of unarticulated norms terrifying in their very indeterminacy. Each discourse proposes moreover to remedy that marginal behaviour with a single, more radical act of marginalization: what the campaigning psychiatrists of the 1820s and 30s presented as the complementary processes of interdiction, meaning legal disenfranchisement, and isolement [isolation], in the sense of physical institutionalization. ${ }^{18}$ In fashioning his fictional interdiction, Balzac deliberately arranges matters to foreground these normative processes. The normality or otherwise of the marquis d'Espard's behaviour is, on the face of it at least, the 'problem' posed by the text, and is presented to the reader in a calculatedly eyecatching manner. Bianchon, having been persuaded by Rastignac to intercede on Mme d'Espard's behalf, visits his uncle Popinot at his home, and draws the juge d'instruction's attention to Mme d'Espard's suit. Sure enough, on Popinot's desk is a brief submitted to the court on behalf of Mme d'Espard, whose text is then redacted in full for the reader's benefit. What follows is one of those bravura displays of narrative and discursive competence in which Balzac consistently excelled; not simply an economical and dramatically very effective mode of exposition, the brief is also a stylistic set-piece in which voices and discourses blend in a luxurious polyglossia. ${ }^{19}$ Even within the story, the text that Popinot reads aloud is a complex act of mutual ventriloquism, in which Mme d'Espard speaks through her disreputable attorney Desroches, who in turn speaks in the name of Mme d'Espard, with neither being exactly accountable for its contents: 'Je ne sais pas ce que l'avoué m’a fait dire’ [I don’t know what my attorney has had me say; 461] is Mme d'Espard's evasive response, when Popinot draws her attention to one of the brief's more tendentious moments. Yet at the level of text, it is of course Balzac who ventriloquizes and is ventriloquized here: the realist novelist speaks a

\footnotetext{
${ }^{18}$ See Goldstein, Console and Classify, pp. 291-2.

19 See Mikhail M. Bakhtin, 'Discourse in the Novel,' in The Dialogic Imagination: Four Essays, ed. by Michael Holquist, trans. by Caryl Emerson and Michael Holquist (University of Texas Press, 1981), pp. 259-422.
} 
language dictated by the Code, yet adapts that language for the purposes of narrative exposition and characterization.

In performing this double duty, the brief is almost perfect: addressed, as legally-minded commentators have been eager to acknowledge, directly to the real procedural requirements of the codes (even if Balzac slips up in citing article 486, rather than 489, as the first of the Code’s provisions on interdiction), but more importantly, persuasive, weaving a compelling narrative of mental decline. ${ }^{20}$ In this respect, this text within a text emphasizes the common features of the attorney's and the novelist's art, their shared duty to produce a narrative which will strike the intended audience - judge, jury, reader - as having the ring of truth. Elsewhere, indeed, Balzac notes that the duty of an attorney is to 'opposer un roman probable au roman improbable' [oppose a likely story to the unlikely story] advanced by the other side (VIII: 656). And yet, importantly, Desroches's opening gambit in his brief is to note that it is particularly difficult to do this with respect to the recent financial conduct of the marquis d'Espard:

'Depuis longtemps tous les revenus que procurent les biens du marquis d'Espard passent, sans causes plausibles et sans avantages, même temporaires, à une vieille femme de qui la laideur repoussante est généralement remarquée, et nommée madame Jeanrenaud. [....] Aucune raison, même prise parmi celles que la morale et la loi réprouvent également, ne peut justifier l'empire que la dame veuve Jeanrenaud a pris sur le marquis d'Espard [...]' (443-4)

[For some time, all the income generated by the marquis d'Espard's property has gone, without plausible cause and to no advantage, however short-lived, to an old woman widely acknowledged to be repulsively ugly, by the name of Jeanrenaud. No reason, not even of the sort that morality and the law deplore in equal measure, can justify the influence that the widow Jeanrenaud has acquired over the marquis d'Espard.]

\footnotetext{
${ }^{20}$ See for instance Peytel, Balzac, p. 180; and Fanny Garcia, 'Les Incapables', in Balzac romancier du droit, ed. by Nicolas Dissaux (LexisNexis, 2012), pp. 147-57 (p. 152).
} 
The brief gives other evidence - notably, again, the allegedly monomaniacal obsession with China - of the marquis's altered mental state, but for the time being I should like to stick with this first allegation. M. d'Espard has, it seems, been channelling very substantial sums of money outside his own family, to Mme Jeanrenaud and her adult son. This, to be sure, is odd behaviour from a certain point of view: that of morality and law. The Civil Code's père de famille was, as we have seen, first and foremost the steward of his own patrimony, and the duty of husbandry imposed on him by the Code was a matter of pressing social importance. Yet if the marquis d'Espard's conduct flies in the face of one set of conventions (that of the Code), it might yet be reasonable according to another: d'Espard might, Desroches implies, have reasons 'que la morale et la loi réprouvent' (italicized in the text) for behaving as he does. The widow Jeanrenaud might, that is, be his mistress, and while this state of affairs would certainly violate the provisions of the codes (both civil and even penal), it would nevertheless be in full conformity with what men of experience know about the way of the world. But this is precisely Desroches's point: married men ruin themselves for beauties, yet Mme Jeanrenaud is notoriously ugly, so even this secondary set of 'illegitimate' conventions will not serve to explain the marquis's behaviour. All that will make sense of these perplexing facts, then, the only conceivable 'cause occulte' [hidden cause] that can explain the case, is madness.

\section{Implausible Conduct}

What the brief does, in other words, is attempt to interpret a set of facts according to a series of maxims about what constitutes normal behaviour, in search of a reading that will make seemingly odd conduct appear - to use Desroches's own word - plausible. My point, as the reader may have guessed, is that the novella in this way begins self-reflexively to consider questions of verisimilitude. We evaluate the plausibility of narratives, as Gérard Genette has argued in an influential essay, through reference to a body of 'maxims and presuppositions 
[préjugés] that constitute at once a vision of the world and a system of values.' Literary verisimilitude thus turns on an equivalence or an equivocation - often imperceptible - between what we might call the normative and the probabilistic meanings of the verb devoir, replicated in the English should, must, and ought: that which our knowledge of the world tells us ought to happen (probabilistically) given a certain set of circumstances, we think ought to happen (normatively) in a literary work in which similar circumstances are presented. ${ }^{21}$ In the same way, Desroches's brief tests out a number of 'maxims and presuppositions,' taking the reader through a series of implied or explicit must propositions whose slippery, shifting modality is all part of their persuasive effect: a married man, article 213 of the Civil Code tells us, 'must protect his wife' [doit protection à sa femme], yet M. d'Espard's extramarital expenditure is preventing him from complying fully with this norm; he must, then, be having an affair; but Mme Jeanrenaud is ugly, so that mustn't be it; instead, then, he must be mad; in which case as the Civil Code inevitably has it - he must be interdit ('The adult in a habitual state of imbecility [...] must [doit] be interdit'; art. 489, emphasis mine). This matters, to be clear, because the preliminary facts of Desroches's brief are the same as the preliminary facts of Balzac's novella. While the interpretation offered in the brief is Desroches's and Mme d'Espard's, and is consequently self-serving, the narrative data on which it is based are those of Balzac's own plot. So if the interpretive maxims applied to the facts by the attorney are not the correct ones - as everything we know about narrative and suspense tells us they cannot be at this stage in the story - it will be Balzac's responsibility as a novelist to supply an explanation for his character's conduct that will conform at least as well to his reader's own maxims, to provide some other 'cause occulte' that will be at least equally 'plausible.' He must, precisely, 'opposer un roman probable' to another - but this time, to one that seems all too probable.

\footnotetext{
${ }^{21}$ Gérard Genette, ‘Vraisemblance et motivation,’ in Figures II (Seuil, 1969), pp. 71-99 (pp. 73, 72).
} 
In the short term, of course, this is also a narrative strategy: the search for an explanation will be the novella's driving energy, with the reader's following of the plot and the magistrate's instruction - both processes of discovery - neatly doubling each other. On the first day, Popinot allows Bianchon to persuade him to pay a visit to the marquise d'Espard at her home - a polite gesture in honour of a grande dame, but a bending of the rules (she should be summoned to his cabinet) that will matter later. At Mme d'Espard's sumptuous hôtel particulier, Popinot's trained eye swiftly identifies the self-serving motivations of the lady's suit: judging by the lavishly refurbished interior, Popinot surmises that the marquise must have at least a hundred thousand francs of debt, whence her eagerness to gain access to her husband's fortune. Mme d'Espard and her entourage, meanwhile, take note of Popinot's sceptical attitude and understand that he is unlikely to favour their cause. On the second day, Popinot summons the woman Jeanrenaud, who appears, every bit as ugly as promised, and is genuinely appalled when the word 'séduction' is spoken. She has done no such thing; she is a respectable person, as is M. d'Espard; she cannot reveal why he has given her the sums he has, but will relinquish them sooner than see him slandered. On the third day, Popinot is under the weather with a headcold, and decides to take the day off; the narrator heavy-handedly directs us to take note of this delay, which, like Popinot's slight deviation from procedure in visiting Mme d'Espard, we sense will become important later. It is on the fourth day, then, that Popinot finally sets out in pursuit of the much-desired explanation for the marquis d'Espard's conduct, by visiting the man himself.

This visit will necessitate a trip to a place that the text presents as being in some sense 'marginal': the Latin Quarter, in the very heart of the city to be sure, but whose narrow medieval streets were associated in this period with poverty, student bohemianism, and insalubrious living conditions. Mme d'Espard's brief has already made clear that for her husband to dwell in such a neighbourhood is 'indigne de son nom et de sa qualité' [unworthy 
of his name and rank; 446], and advances this bizarre decision as evidence of the marquis's insanity; while even the supposedly impartial narrator comments at length upon the social decline and physical degradation of the area and of the marquis's building, once the home of a cardinal, but now rotten and abandoned to 'd'obscurs locataires' [common tenants; 471]. Significantly, however - though, to borrow a trick from Balzac, I shall say why later - this is a short hop for Popinot: he and the marquis d'Espard live in the same quartier. Entering the building, Popinot encounters the concierge, who feels duty-bound to inform the judge that M. d'Espard is indeed quite mad; the same opinion is held, the narrator assures us, by the other tenants, who can find no 'motifs raisonnables' [reasonable motivations; 473] for - that is, whose repertoire of 'maxims' can supply no satisfactory interpretation of - the marquis's many odd behaviours. Encountering the alleged lunatic for the first time, Popinot finds a somewhat elegant man with an over-pronounced forehead which the phrenologist in Balzac claims 'aurait pu faire croire en effet à quelque peu de folie' [might well have led one to think him slightly mad; 476], and who is already in some sense partially interdit: the narrator notes his 'parler indécis’ [hesitating speech] and his stutter (476). In conversation, his attention often seems to wander; his extreme personal economy means he is shabbily dressed. All of these 'singularités' [peculiarities], the narrator explains, 'contribuaient à confirmer sa prétendue folie' [went to confirm his alleged insanity; 476].

The interview that follows is supposed to satisfy the judge's, the Code's, and the reader's requirements all at once: the evidence for his 'prétendue folie' having been briefly recapped for us by the preceding pages, the marquis now speaks in his own defence. First, Popinot confronts him with the accusation concerning the monies made over to Mme Jeanrenaud and her son; M. d'Espard resignedly explains. Some years ago, in the process of selling some property in order to service debts brought by his wife to their marriage, the marquis had made a shocking discovery: one of his family's estates had been acquired by 
means of an illegal conspiracy to expropriate a Huguenot landowner in the aftermath of the revocation of the Edict of Nantes (1685). The marquis, perceiving this spoliation as a blot on his family's honour, immediately resolved to make restitution to the living descendants of the unfortunate Protestant: the Jeanrenauds, mère et fils. Through careful scrimping, he has now acquitted himself of the debt. He has also elected to do so in the utmost secrecy, since to reveal the theft would disgrace his treasured family name. In telling this story, the narrator informs us, the marquis's voice has lost its stammering and hesitant quality - clearly, the man is perfectly sane. The rest then explains itself. D’Espard is obsessed with China because he is self-publishing and selling a highly profitable pictorial encyclopaedia of that great empire, in order to support an old friend from his Emigration days who has returned to France penniless; and besides, what's so mad about being interested in China? He lodges in the Latin Quarter because it is all he can afford - and we conclude that his estrangement from his wife has more to do with her flaws than his, since their rupture dates from the moment he revealed to her his intention to pay the Jeanrenauds back for their ancestor's loss, a proposal she evidently did not entirely favour. All of his present position thus stems from his determination to make good on that debt of honour.

This, then, is the better explanation of the marquis's behaviour that we have been waiting for, and most critical accounts of the novella applaud it as a shimmering example of rectitude in the moral quagmire of Balzac's fictional universe. Certainly, the rash of axiological language that erupts once the story is told - sublimity, nobility, divinity, purity, dignity and charity jostle each other in a single paragraph (491) - works about as coercively as a thirdperson narration can to enforce this view of things upon the reader. At least one other possible reaction to the restitution is recorded in the text, however: Mme d'Espard's, as recounted by her husband: ‘Quand je lui proposai [...] une restitution [...], Mme d’Espard me traita de fou’ [When I suggested we make restitution, Mme d'Espard called me mad; 485]. Her reaction is 
important because it reveals that the marquis's story, though offered in place of the narrative of madness spun by Desroches's brief, has nevertheless not entirely supplanted the vocabulary of mental dysfunction found there. Though that document has now been revealed to be deeply mendacious in all kinds of ways, it contains at its heart a perverse sort of good faith: for while she knows her husband is not a lunatic of the sort who require shutting up in an asylum, the project of restitution strikes Mme d'Espard as, in a different way, pure folly. Nothing, for a start, legally compels M. d'Espard to restore the fortune, a point the text belabours through the voice of Popinot. The law is on the marquis's side: the doctrine known as prescription (the word refers, equally, to time-limits on criminal sanctions and, in the Civil Code, to the acquisition of title by long possession alone; see art. 2262) establishes beyond doubt that $\mathrm{M}$. d'Espard's fortune is his own. The restitution thus conforms, as Popinot puts it, only to 'un principe de probité très étendu’ [a very extended principle of probity; 490), and such an eccentric extension of the principle of probity strikes Mme d'Espard, for one, as the work of a minor madman.

Now the text's axiological framing has already primed the reader to deplore a view such as this. In that opening conversation between Bianchon and Rastignac, the world-weary doctor complains that 'quand j'ai voulu donner une poignée de main à la Vertu, je l'ai trouvée grelottant dans un grenier [...] et passant pour une folle, une originale ou une bête' [whenever I have wanted to shake hands with Virtue, I have found her shivering in an attic, and taken for mad, eccentric or stupid; 424]. On the face of it, this sentence supplies the reader in advance with the tale's moral: the wickedness of modern society has made 'Virtue' hopelessly marginal. This reading is probably fair enough, though it risks oversimplification in its suggestion that what opposes Virtue is Vice, and that the marquis's sense of morality is rendered marginal only by the prevalence of immorality. Yet it is not impossible to find a legitimate principle that speaks against M. d'Espard's behaviour - and that principle is to be found, inevitably, in the 
law. It is, after all, not simply the case that the restitution is not required by the letter of the law; in fact, M. d'Espard's scruples also fly in the face of the spirit of the law - or more specifically of the Code - insofar as that spirit emphasized the careful management of patrimony and the precise balancing of individuals' self-interest. The Code's expectation that the père de famille will parsimoniously conserve his patrimony within his family was not rooted in some malevolent urge to stifle virtue, but in the belief that this arrangement was most conducive to social stability; and of course, the doctrine of prescription in its various forms exists for the very same reason. (Popinot himself acknowledges as much, when he points out that if every family whose wealth was illegitimately acquired generations ago were required to make restitution, there would be hardly any legitimate landowners left; 490). In the moral universe of the Civil Code, generosity - meaning, here, giving more than one is required to, to anybody, for any reason - is not a virtue in the père de famille; if anything, it is a vice - and, more specifically, the vice of his wife. In discussing the 'notorious misogyny' of the Code's drafters, Xavier Martin points out their belief in the 'incapacity - in some sense physiological [technique] in nature - of the female brain, perpetually hindered by the heart, properly to assume [...] a socio-familial function that the legislator intends to be stabilizing'.22 For the drafters, he continues, 'the particular disadvantage of woman was that she was liable to emotional disturbances that made her regrettably generous'. ${ }^{23}$ The marquis, too, locates his restitutive tendencies in his heart: 'leur tribunal [...] était là' [the judge to whom they could appeal was here], he says of the Jeanrenauds, 'en se frappant le cœur’ [striking his heart; 484]. Seeing such recklessly unfatherlike behaviour in her husband, Mme d'Espard - who is, of course, all head - can reasonably claim to have felt called upon to assume his responsibilities vis-a-vis his children and, as it would happen, his own wealth: ‘j'ai senti que je devais

\footnotetext{
${ }^{22}$ Xavier Martin, Mythologie du Code Napoléon: aux soubassements de la France moderne (Dominique Martin Morin, 2003), pp. 270-1 (my translation; this sentence is omitted in the English version).

${ }^{23}$ Martin, 'The Paternal Role', p. 33; translation modified.
} 
remplacer leur père' [I felt I had to replace their father; 467], she tells Popinot in the course of their interview. The gender inversion anticipated by article 507, then, has in some sense already happened in the d'Espard household, at the level of economic and emotional attitudes.

So much for Mme d'Espard's reaction to the marquis's revelation; what about the reader's? Might we not feel a little disappointed, even cheated, by what we have learned? Might we not, indeed, respond to the marquis's heroic act of restitution as the comte de Bussy, among others, did to Mme de Lafayette's La Princesse de Clèves (in an observation quoted by Genette): 'Mme de Cleves’s confession to her husband is extravagant and ought to figure only in a true story; but when one is writing fiction, it is ridiculous to give one's heroine such extraordinary sentiments'? Extraordinariness, in other words, is the preserve of real life; and the marquis d'Espard's conduct is, on the text's own showing, at the very least extraordinary. Just as Mme de Clèves’s confession is, in Genette’s formula, ‘an action without a maxim', so the reader must stretch far indeed to find a 'principe' sufficiently 'étendu' to account for M. d'Espard's restitution. ${ }^{24}$ The law, as we have seen, makes no normative prescription that someone in such a position ought to restore the fortune; and, partly for this reason, the reader's sense is that this is not what a character ought to do in a novel because it is not what he would probably do in 'real life.' The only maxims that suggest the marquis ought to make restitution, meanwhile, are ones presented by the text itself - even if it deplores that they should be so presentable - as marginal and extravagant. Put differently, the marquis’s behaviour just isn't, well, realistic; for as Guy Sagnes notes in his introduction to L'Interdiction, 'restitutions only happen in novels' ${ }^{25}$

But not just any novels. There is one genre in nineteenth-century French literature where such things happen a lot, and in relation to which these questions of plausibility,

\footnotetext{
${ }^{24}$ Genette, 'Vraisemblance et motivation', pp. 71-2, 75.

${ }^{25}$ Introduction to Pléiade edition, p. 420.
} 
verisimilitude, and narrative ‘extravagance’ have consequently been debated particularly hotly. That genre - if it may be called a genre - is women's writing, and specifically the writing of female authors from around 1830 to 1870 . Indeed, Nancy K. Miller has developed Genette’s comments on vraisemblance in La Princesse de Clèves to argue that women's writing in general has historically been victim to male critics' accusations of implausibility and extravagance, so many - usually strategic - failures to recognize women authors' attempts to supply new behavioural maxims in place of those governing male-authored fiction:

The attack on female plots and plausibilities assumes that women cannot or will not obey the rules of fiction. It also assumes that the truth devolving from verisimilitude is male. For sensibility, sensitivity, 'extravagance' - so many code words for feminine in our culture that the attack is in fact tautological - are taken not merely to be inferior modalities of production but deviations from some obvious truth. ${ }^{26}$

Nowhere have these tactics of generic marginalization been more effective than in the formation of the nineteenth-century French literary canon, where 'sensibility' and 'sensitivity' - to which we can add, perhaps most importantly, sentimentality - came by the turn of the twentieth century to be considered not only indicatively feminine, but indicative of the very lowest of literary genres. In her landmark study of the work of George Sand, Naomi Schor traces the origins of this marginalization in the literary quarrels of the 1830s and '40s, which pitted the mimetic, descriptive aesthetics of what would come to be called 'realism' against what was already referred to - including by Sand herself - as 'idealism': a form of literary representation that refused to accept things 'as they were', and offered instead a morally prescriptive vision of better men, better women, and better societies. ${ }^{27}$ While idealism was not from the outset an exclusively female literary mode, it began from 1830 onward to become closely associated with female writers and readers, and with sentimentalism; moreover, Sand's

\footnotetext{
${ }^{26}$ Nancy K. Miller, “Emphasis Added: Plots and Plausibilities in Women’s Fiction”, 96 PMLA 36 (p. 46).

${ }^{27}$ See Naomi Schor, George Sand and Idealism (Columbia University Press, 1993).
} 
own work often represents a willingness to fly in the face of received maxims - to behave, in Nancy K. Miller’s thought-provoking word, 'idiopathically' - as the paradoxical privilege of female characters whom patriarchal society has left with nothing to lose.

It is thus possible to see in Balzac's marquis d'Espard a figure not only of gender, but also of genre non-conformity: though a character in a work that will come to be seen as the very model of realist literature, he behaves and is described as if he were a character - indeed, a heroine - in a work of idealist fiction. The tension between the flawed law and a higher moral duty that lies at the heart of the marquis's tale would sure enough soon become a mainstay of women's writing: as Margaret Cohen notes, the opposition between le Code and le cour - the self-same opposition alluded to by the marquis - is the central conceptual binarism of the female-authored 'sentimental social novels' of the 1840s and '50s. ${ }^{28}$ (Indeed, M. d'Espard's precise predicament - the moral obligation to restore to another an inheritance that is in legal terms indisputably his - was a recurrent plot device of sentimental, and especially Catholic, women's writing of later decades. $)^{29}$ So: what is going on? The simplest path of argument would be to insist, following on from Schor, that in the mid-1830s the idealist and proto-realist tendencies were not rigorously defined or separate, had not yet ossified into distinct genres and still less into gendered aesthetic patterns, and remained co-present in many works; we ought not, then, to be surprised to find this idealist enclave in Balzac's realist universe. No doubt there is some truth in this argument, yet to stop there would be to miss a crucial fact of the composition of the novella. For while the marquis d'Espard's tale of restitution represents to be sure a sort of idealist micro-narrative at the heart of the text, that tale is not coterminous with the story of L'Interdiction - which involves instead the evaluation of the marquis's conduct by the judge Popinot. Balzac's novella, that is, presents the idealist tale at its centre

\footnotetext{
${ }^{28}$ See Margaret Cohen, The Sentimental Education of the Novel (Princeton University Press, 1999), pp. 139-43.

${ }^{29}$ See Andrew J. Counter, Inheritance in Nineteenth-Century French Culture: Wealth, Knowledge and the Family (Legenda, 2010), pp. 139-42.
} 
not as self-evident, but as an object of scrutiny and judgement. If it is to be adjudged plausible and thereby accede to the status of 'truth', it will have to be told again - not, this time, by the marquis (a suspected madman), but by the impartial judge, in the report that ought in theory to determine the outcome of the case. The final element necessary to an understanding of L'Interdiction is, then, consideration of the narrative frame: not of the facts of the case, but of the act of judgement - and the judge.

\section{The Admirable Popinot}

Judge Popinot is an admirable character. We know this because the narrator tells us so, many times: he is an 'homme supérieur' [superior man; 432], a 'profond criminaliste' [shrewd criminal jurist; 433], possessed of a 'génie d’observation' [genius for observation; 436], and likened - in one of Balzac's favoured rhetorical moves - to geniuses of other fields of knowledge, the naturalist Cuvier and the surgeon 'Desplein' (based on the historical Dupuytren; 433). Critics of the novella tend to take these claims at face value - indeed, they queue up to echo them, and especially Bianchon's punchy observation that Popinot 'est juge comme la mort est la mort' [is a judge as death is death; 426]. ${ }^{30}$ Yet one might wonder whether this phrase doesn't sound more meaningful than it really is; in any case, it is remarkable principally by its hyperbole, and while hyperbole does not necessarily indicate irony, the two are at the very least known associates. This is in fact one of a number of moments when the text’s efforts to make Popinot 'embody a dream of perfect justice’ (in Michel Lichtlé’s phrase) seem oddly half-hearted or self-undermining. ${ }^{31}$ In an elaborate passage, for instance, the narrator expatiates on what he alleges are the two elements of any legal case: le droit et l'équité, law and equity (432-3). Equity, we are told, arises from facts, and law, from the application of

\footnotetext{
${ }^{30}$ See for instance Peytel, Balzac, on 'the admirable Popinot' (p. 89); Mourier, Balzac, on the 'excellent JeanJules Popinot, model of the judge of integrity' (p. 54); and Lichtlé, Balzac, on - more sophisticatedly - Popinot as an embodiment of 'a dream of perfect justice' (p. 220).

${ }^{31}$ Lichtlé, Balzac, p. 220.
} 
principles to facts (?); a man can be right in equity, wrong in law (fair enough). The narrator continues in this vein until we reach the pay-off: Popinot's special genius, it seems, means that he has 'frotté la lettre de la loi dans l'esprit des faits' [shaped the letter of the law to the spirit of the facts; 433].

I would submit that this phrase is, legally speaking, close to meaningless. We are presumably supposed to understand from it that Popinot has found a way of handing down judgements (what the narrator calls 'd'équitables arrêts', equitable rulings) in the interstices of the Code, which, as the man himself puts it, 'n’est pas sans défauts' [is not without its flaws; 468]. Yet the narrator's claim that 'il concluait souvent contre le droit en faveur de l'équité' [he often concluded against law in favour of equity; 433] is of course pure rhetoric: no judge can conclude 'against' law, but only within the spaces left between its provisions. The rulings that populate those spaces are known in French as la jurisprudence, the general term for the non-binding yet persuasive decisions of the nation's various tribunals that shape the application of the codes' provisions to individual cases; part of the aim of the Napoleonic codification, moreover, was to limit the need for, and the scope of, such case-by-case decisions as much as possible. In Le Père Goriot, as we have already seen, this jurisprudence supplies the vehicle for a memorable metaphor: what the hero, law student Rastignac, must really learn, we are told, is 'ce Droit parisien [...], cette haute jurisprudence sociale qui, bien apprise et bien pratiquée, mène à tout' [that Parisian Law, that high social jurisprudence which, studied and practised well, can take one anywhere; 109]. If the earlier novel situates this savoir-faire as an object of desire (Rastignac's and thus the reader's), the novella of 1836 seems to treat it as a symptom of the wicked way of the world: for is it not precisely this social jurisprudence that Rastignac employs against the marquis d'Espard, when he pulls some strings with Bianchon, who pulls some strings with Popinot, in the hope that Popinot will pull some strings on behalf of Mme d'Espard? The marquise and her entourage are it seems every bit as able as Popinot to inhabit 
the space between the provisions of the Code, to shape a suppler sort of law to meet the needs of circumstances. The implied distinction between Popinot’s ‘équitables arrêts’ and society’s crafty jurisprudence is thus ultimately unprincipled: any moral preference one might express for one or other of these forms of legal casuistry would itself be rooted in mere casuistry. Put differently, Popinot's heroic equity is really empty rhetoric, as befits a character whom the text is so eager to turn into a mere figure, an allegory of Justice.

At other moments, indeed, the text seems deliberately to undermine this allegorical presentation of Popinot - most importantly, in the information we are given about his private life. Popinot is so busy, we learn, that he has no time to think about his dress; his judge's robes are thus filthy, faded and old. The admirers of 'l'admirable Popinot' are quick to follow the narrator in finding in these details proof positive of the magistrate's authentic genius. Yet this personal sloppiness is twice referred to as his 'incurie' [inattention; 430, 440], and the same Balzac wrote in his Pathologie de la vie sociale (1839) that 'l'incurie de la toilette est un suicide moral' [inattention in personal care is a moral suicide; 12, 252]. The word is in any case rich in connotations, all of which are troubling for the allegorical image of Popinot: the priest whom Popinot resembles in his pious concern for the virtue of others is, in French, a curé, one to whom is accorded 'cure d'âmes' [care of souls]; the doctor, like the renowned 'Desplein' to whom Popinot is likened by the narrator, is one who administers 'cures' (la cure in French); and, of course, the judge who doles out justice does so in a court - curia - where, in theory, no detail should go overlooked. Nor does Balzac present him as quite the model of the impartial, detached magistrate: Popinot, as we have seen, lives in the Latin Quarter - the quarter, the narrator notes, ‘qui envoie [...] le plus de prévenus à la Police correctionnelle’ [which sends the most defendants before the criminal justice system; 427]. Popinot dwells, that is, among the very people he is called upon to judge, and when the reader first finds him at home, surrounded by a throng of poor devils from the Latin Quarter, the narrator observes that 'le 
magistrat n’était pas le personnage le moins pittoresque au milieu de cette assemblée’ [the magistrate was not the least colourful personage in this grouping; 438] - meaning less that he stands out than that he blends in among the poorly dressed, poorly groomed, exotic-looking low-lives. They gather in his house for an important reason: in addition to his judicial functions, Popinot runs an elaborate charitable operation out of his home, working from first light to provide small loans or donations to the needy and stricken in his neighbourhood, maintaining scrupulous records of who has received what and for how long. This is all well and good, of course, and the narrator describes Popinot's missionary work with obvious approval - until, that is, we encounter the following extraordinary phrase, describing how Popinot's operation grew to its current quasi-industrial proportions: 'La bienfaisance a son entraînement comme les vices ont le leur. La charité dévore la bourse d'un saint comme la roulette mange les biens du joueur, graduellement' [one can become carried away by good deeds as much as by vice. Charity devours the contents of a saint's purse just as roulette gobbles a gambler's resources, gradually; 434]. It is difficult to read these sentences as suggesting anything other than that Popinot's charitable enterprise, however worthy, is somehow excessive, encouraged more by weakness than by strength of character, and that his great generosity ultimately threatens his ruin.

The reader may have noticed that, taken together, these details reveal that the man assigned to be the marquis d'Espard's judge is, in fact, the marquis d'Espard's double. Both strike strangers as shabby-looking and odd. Both choose to dwell in the same gone-to-seed neighbourhood, and the judge's visit to the marquis even ends with the former planning to lease the latter's apartment should the marquis elect to vacate it (491) - the second time, we might note, that a character in the novel plans to 'take the place' of M. d'Espard. (Readers of the unfinished Les Petits Bourgeois know that this move will in fact come to pass.) Both seem compelled to acts of generosity that observers - and, in Popinot's case, the narrator himself - 
consider excessive and potentially reckless in their disregard for the giver's own economic interests. And both are obvious idealists: the marquis's story of restitution and redemption moves the judge profoundly, and the narrator insists rather ponderously on the meeting of minds that occurs between the two: 'Ces deux natures si pleines, si riches, [...] s’étaient mises à l'unisson doucement, [...] comme si deux lumières se fussent confondues' [these two personalities, each so full and rich, had come gently into unison, like two lights blending; 491]. Given these shared qualities and the moment of idealized, cosmic conjunction between the two men, then, there can be little doubt in whose favour Popinot will rule. He returns home to write his report, warning the marquis that his wife is out to get him.

Yet the two men have a final, crucial similarity: both these idealists are perceived by their entourage as hopelessly unworldly, and find themselves marginalized as a consequence. In introducing Popinot, the narrator explains that our hero was never an 'intrigant' [intriguer; 431], and that his colleagues consider him 'un esprit peu pratique' [an impractical soul; 433]. He has therefore found himself 'reculé', 'exporté' and 'repoussé' [side-lined, farmed-out, pushed away; 431] to progressively lower rungs of the judicial hierarchy each time the Ministry found it expedient to promote someone else. In short, and for all his skill in équité, he has never learned his jurisprudence sociale, and the story holds one final marginalization in store for him as a result. Arriving at the Palace of Justice the next morning, report in hand, Popinot is taken aside by the President of his section. The delay in drafting the report occasioned by Popinot's head-cold two days before has given the marquise’s accomplices time to act. The President has been casually informed that, earlier this week, Popinot took tea (in fact he declined food and drink, as per the letter of the Code of Civil Procedure) at the home of the marquise d'Espard, a party in one of his cases. Of course the President understands that this is a niaiserie (492), a silly misunderstanding, a trivial peccadillo, but rules are rules - the d'Espard case has now been removed from Popinot's docket and reassigned to a thrusting younger colleague. The 
judge who is the marquis's kindred spirit has been side-lined, ironically, lest he be thought to be favouring the marquise's cause. Popinot attempts to submit his report, which we know must contain quite the opposite ruling - “"Mais, monsieur le président, si vous connaissiez l’espèce,” dit le juge en essayant de tirer son rapport de sa poche’ [“"But Mr President, if you knew the facts of the case," said the judge, attempting to produce his report from his pocket'; 492] - but the President has already moved on.

The interdiction of the title, then, is arguably not that of the marquis d'Espard at all: indeed, the story cleverly ends with that suit unresolved (though even more cleverly, a later novel reveals that the marquise in fact lost her case - though only because she offended the Minister of Justice!). Instead, the novella's great interdit is Popinot, who is prevented from rendering what we know would have been a most equitable ruling by the scheming of those with power and social savoir-faire. The story ends, indeed, with Popinot falling silent 'disdaining', the narrator asserts in the final sentence, to contest the lie told against him (495). The would-be allegorical figure of Justice is thus silenced by the workings of what in French is also called la justice - that is, the fallible, worldly institutions of law - in an instance of a psychodrama that is fundamental to modern western societies, in which Law is called upon to serve at once as the symbol of society's highest ambitions for itself, and of its almost inevitable failure to live up to those ambitions. That failure is represented most eloquently in the novella's denouement by another kind of silence - that of the younger colleague, Camusot, to whom the case has been transferred. Seeing Popinot's dismay, we are told, 'il ne put retenir un sourire ironique’ [he could not contain an ironic smile; 493].

\section{Conclusion}

What, finally, of Popinot's report? Unlike the brief for Mme d'Espard, quoted in full and lengthily commented upon for the reader, this second legal document is suppressed; though we 
know it has been written, it is despatched beyond the margins of the novella itself, forever buried in the dark of Popinot's pocket. We can of course infer what it contains: the vindication of the marquis's sanity and an admiring retelling of his idealist tale of restitution. The silencing of Popinot and the suppression of his report thus yokes together the allegorical vision of Justice and the idealist mode of narrative in a single moment of marginalization. Both are, to be sure, nice enough, but the text ultimately situates both as somehow impractical, inopportune, or extraneous. The text Popinot has authored meets the same fate as decades, if not centuries, of women’s writing, as described by Miller, Schor and Cohen: condescendingly regarded as wellmeant, yet ultimately dismissed - never quite substantively, but always somehow procedurally, formally - as inadmissible. Despite appearances, then, L'Interdiction does not find Balzac in a brief idealist flight of fancy, but at his most characteristically realist. In this novella, the ideal is brought into the literary frame only so that the author may demonstrate, with a certain (hypocritical?) regret, that it has no place; that it is doomed, inevitably, to succumb to the demands of reality.

Andrew J. Counter

New College, Oxford 